\title{
CRITICAL MANUFACTURING PROCESS IN TYRE MANUFACTURING INDUSTRY: A CASE STUDY OF THE INDIAN SSES
}

\author{
Hardeep Singh \\ Research Scholar, School of Engineering, GD Goenka University, Gurugram, India \\ Dr. Shakun Preet Kaur \\ Associate Professor, School of Engineering, GD Goenka University, Gurugram, India
}

\begin{abstract}
Indian tyre industry is adopting new technologies for improving its products to sustain in the global competition. The main focus is to develop efficient and durable tyres at affordable price by finding the most critical manufacturing process in tyre manufacturing. This paper concentrates on finding the most critical manufacturing process. The views of the experts of various fields have been considered for the same. The result shows that the curing of tyre is the most critical process followed by tyre building. The study proposes the process that can be optimized to enhance the quality of tyre manufacturing.
\end{abstract}

Key words: AHP, Critical manufacturing process, Tyre manufacturing industry.

Cite this Article: Hardeep Singh, Dr. Shakun Preet Kaur, Critical Manufacturing Process in Tyre Manufacturing Industry: A Case Study of the Indian SSES, International Journal of Advanced Research in Engineering and Technology, 10 (3), 2019, pp 87-93.

http://iaeme.com/Home/issue/IJARET?Volume=10\&Issue $=3$

\section{INTRODUCTION}

Due to globalization of the economy, the Indian tyre industry is trying its best to improve the product affordability in world market. It is trying to adopt flexible international technologies to fit into the competition. Presently there are 40 registered companies in the tyre sector in India. The tyre industry is prime choice for private investors to invest their money which is approximately Rs 36000 crore. The main reason for the investors for their investment is that it is the faster growing industry in India with 3\% of total GDP. This industry is the major consumer of the domestic rubber market and import about $45 \%$ of its share with high import tax [1]. The major factors that affects the demand of tyre as a product includes re-treading of tyres, transportation volumes, network of roads, execution of vehicle loading rules and exports. The main challenge for the tyre industry is to develop affordable, efficient and durable tyres at affordable price. To overcome this challenge companies need to closely look into its controllable internal processes used in the manufacturing of tyres. The most critical process 
should be identified and optimized for achieving the goal of sustaining in the competitive market.

The most critical process can be identified by using Analytical Hierarchy Process. Analytical Hierarchy Process is a decision making process used to solve complex decision problems which was introduced by Saaty [2]. It is always preferred by the researchers over other decision making processes as the input data required for the same is easy to collect. The pairwise comparison of relevant data is used for ranking of all input parameters.

A typical tyre manufacturing unit uses the following processes for the manufacturing of tyres:

- Mixing: Tyre manufacturing process starts with mixing the proper quantity of natural rubber, synthetic rubber and various chemicals in a mixture known as Banbury mixer. Rubber mix depends upon the desired properties of the product to be manufactured.

- Milling: Milling is a process in which homogenous rubber mixture is passed through a mill which convert it into long strips. To maintain the temperature of these strips these are made to pass through the cooled air or water. To prevent their sticking during cooling these strips are coated with powder or anti-tack solution.

- Extruding: Extruder are used to fabricate treads and sidewall components of tyre. During this operation, the strips fabricated by milling process are passed through a die which convert it into various shapes.

- Calendaring: Calendaring is a process in which thin rubber coated fiber sheets are produced by squeezing reinforcing fibre materials into rubber.

- Building: All rubber components of tyre are assembled to make a raw tyre which is called green tyre. Sometimes it is necessary to use adhesives to increase their bonding capacity. This process includes fabrication, reinforcing and bonding process.

- Curing: The green tyre is cured in a metallic mould. There is a chance of sticking of this tyre to the inside of the mould due to high heat. To prevent its sicking into mould it is coated with a liquid. During curing of tyre is forced against the mould which results in formation of tread and side wall pattern of tyre. The time period for the curing process depends on the specification of the tyre being made.

- Finishing: After curing tyres goes for inspection and finishing process. The final finishing includes printing, washing and buffing.

\section{LITERATURE REVIEW}

From the literature it is observed that automobile sector is one of the main area which is responsible for the generation of waste in developing countries [3,4] and in all of them the tyre waste more considerable. In past researchers were more focused on studying the profitability of tyre remanufacturing units [5]. They worked on system design for tyre reworking as there is large number of used tyre available per year. They proposed a model for provides the decisions related to the number of facilities to open, their locations, and also the allocation of the corresponding product flows [6]. They also proposed that the scrap tyres can be used in other production processes to minimize the use of non-renewable materials. For the same they did the value analysis of scrap tyres in cement industry by replacing petroleum coke for scrap tires [7]. A few researchers tried to find out the most dominating factor for end of life in tyre usage. They proposed a framework for analysis of these factors and validate the same in Indian scenario [8].

In addition to all this work which is on tyre remanufacturing a few researchers also proposed some methodologies to improve the processes in tyre manufacturing units. Gupta V et al. [9] proposed to implement lean Six-Sigma methodology to reduce the defects in a radial tyre 
manufacturing company. Lean Six-Sigma methodologies were merged to analyse the problem with the help of root-cause analysis. During analysis it was observed that the presence of foreign particles in the manufacturing environment, under-ageing and over-ageing of tyre components, and inefficient bead winding process, are the factors responsible for rejection of tyres. Gupta V et al. [10] also suggested that financial competency of any manufacturing unit is responsible for integrating lean manufacturing practices in their organization. They concluded that over-processing as well as excessive defects are the most damaging wastes in radial tyre manufacturing. Visakh $\mathrm{M} \mathrm{J}$ and Aravind S [11] tried to optimize the manufacturing process by implementation of Lean Manufacturing. Lean manufacturing is used to identify nonvalue added processes in a tyre manufacturing industry and processes are optimised by using value stream mapping and Taguchi method. Maciej WOJTASZAK [12] solved an industrial problem of tyre manufacturing plant which was producing pneumatic tyres for agricultural machinery named Trelleborg Wheel Systems, Sri Lanka by under of Lean Six Sigma program.

It is also found that analytical hierarchy process can be used for decision making. Chatterjee et al. [13] used Multi criteria analysis for selection of martial in industries. The further research showed that the same process can also be used in environmental planning [14, 15]. A few researchers gives the application of AHP to find out the best alternate in water resource planning by comparing six water management decision problem [16]. They suggested that the initial structure of a problem is equally important as the selection of decision making process. Ustinovichius et al. [17] studied the investment required in construction and Jeffreys [18] for small-scale forestry by using AHP. Method for the selection of tool material was proposed by Chen [19]. Rao and Devim [20] used the same method for material selection by presenting a logical procedure. The proposed procedure helped them to estimate and rank the materials requirements for a particular design. Jayamani $\mathrm{E}$ et al. [4] proved that reinforced polymer matrix composites used in automobile industry for weight reduction of components results in $0.4 \%$ improvement in fuel efficiency.

It is clear from the above mentioned applications of AHP, that the process can also be used in tyre manufacturing industries for finding out the most critical process which is need to be optimized.

\section{METHODOLOGY}

The profit of any industry depends upon the selection of material, selection of process for fabrication, type of machine used and skill of operator. Selection of right type of process and its process parameters plays an important role in the profit of industry. As discussed in section 1 all the processes for manufacturing entire i.e. mixing, milling, extruding, calendaring, building, curing and finishing are included in this study.

\subsection{STEP 1: Collection of Inputs}

The opinions of experts from various fields is thoroughly analyzed by AHP. Taking opinions from experts of various fields will minimize the error. Hence the opinions of various professionals from industry, academics and research is considered. The questionnaires were filled by using nominal-ratio scale of 1 to 9 . The geometric mean of all the filled questioners is taken considered to form a square judgment matrix as shown in table: 
Hardeep Singh, Dr. Shakun Preet Kaur

Table 1 Opinion of Industrial expert

\begin{tabular}{|l|c|c|c|c|c|c|c|}
\hline \multicolumn{1}{|c|}{ Factors } & Mixing & Building & Extruding & Calendaring & Curing & Finishing & Milling \\
\hline Mixing & 1 & $1 / 3$ & 3 & 4 & $1 / 2$ & 7 & 4 \\
\hline Building & 3 & 1 & 2 & 2 & 1 & 5 & 2 \\
\hline Extruding & $1 / 3$ & $1 / 2$ & 1 & 4 & $1 / 3$ & 4 & 2 \\
\hline Calendaring & $1 / 4$ & $1 / 2$ & $1 / 4$ & 1 & $1 / 4$ & 2 & $1 / 2$ \\
\hline Curing & 2 & 1 & 3 & 4 & 1 & 4 & 3 \\
\hline Finishing & $1 / 7$ & $1 / 5$ & $1 / 4$ & $1 / 2$ & $1 / 4$ & 1 & $1 / 2$ \\
\hline Milling & $1 / 4$ & $1 / 2$ & $1 / 2$ & 2 & $1 / 3$ & 2 & 1 \\
\hline
\end{tabular}

Table 2 Opinion of Academia expert

\begin{tabular}{|l|c|c|c|c|c|c|c|}
\hline \multicolumn{1}{|c|}{ Factors } & Mixing & Building & Extruding & Calendaring & Curing & Finishing & Milling \\
\hline Mixing & 1 & $1 / 2$ & 3 & 5 & $1 / 4$ & 7 & 3 \\
\hline Building & 2 & 1 & 4 & 3 & $1 / 3$ & 4 & 3 \\
\hline Extruding & $1 / 3$ & $1 / 4$ & 1 & 4 & $1 / 3$ & 5 & 5 \\
\hline Calendaring & $1 / 5$ & $1 / 3$ & $1 / 4$ & 1 & $1 / 5$ & 3 & $1 / 3$ \\
\hline Curing & 4 & 3 & 3 & 5 & 1 & 7 & 3 \\
\hline Finishing & $1 / 7$ & $1 / 4$ & $1 / 5$ & $1 / 3$ & $1 / 7$ & 1 & $1 / 2$ \\
\hline Milling & $1 / 3$ & $1 / 3$ & $1 / 5$ & 3 & $1 / 3$ & 2 & 1 \\
\hline
\end{tabular}

Table 3 Opinion of Researcher

\begin{tabular}{|l|c|c|c|c|c|c|c|}
\hline \multicolumn{1}{|c|}{ Factors } & Mixing & Building & Extruding & Calendaring & Curing & Finishing & Milling \\
\hline Mixing & 1 & $1 / 3$ & 4 & 5 & $1 / 3$ & 6 & 4 \\
\hline Building & 3 & 1 & 3 & 3 & $1 / 2$ & 6 & 3 \\
\hline Extruding & $1 / 4$ & $1 / 3$ & 1 & 6 & $1 / 4$ & 5 & 3 \\
\hline Calendaring & $1 / 5$ & $1 / 3$ & $1 / 6$ & 1 & $1 / 5$ & 3 & $1 / 3$ \\
\hline Curing & 3 & 2 & 4 & 5 & 1 & 5 & 4 \\
\hline Finishing & $1 / 6$ & $1 / 6$ & $1 / 5$ & $1 / 3$ & $1 / 5$ & 1 & $1 / 3$ \\
\hline Milling & $1 / 4$ & $1 / 3$ & $1 / 3$ & 3 & $1 / 4$ & 3 & 1 \\
\hline
\end{tabular}

Table 4 Geometric Mean Value for decision making

\begin{tabular}{|l|c|c|c|c|c|c|c|}
\hline \multicolumn{1}{|c|}{ Factors } & Mixing & Building & Extruding & Calendaring & Curing & Finishing & Milling \\
\hline Mixing & 1.00 & 0.38 & 3.30 & 4.64 & 0.35 & 6.65 & 3.63 \\
\hline Building & 2.62 & 1.00 & 2.88 & 2.62 & 0.55 & 4.93 & 2.62 \\
\hline Extruding & 0.30 & 0.35 & 1.00 & 4.58 & 0.30 & 4.64 & 3.11 \\
\hline Calendaring & 0.22 & 0.38 & 0.22 & 1.00 & 0.22 & 2.62 & 0.38 \\
\hline Curing & 2.88 & 1.82 & 3.30 & 4.64 & 1.00 & 5.19 & 3.30 \\
\hline Finishing & 0.15 & 0.20 & 0.22 & 0.38 & 0.19 & 1.00 & 0.44 \\
\hline Milling & 0.28 & 0.38 & 0.32 & 2.62 & 0.30 & 2.29 & 1.00 \\
\hline
\end{tabular}

\subsection{STEP 2: Consistency Test}

The consistency of the opinions is checked by calculating the consistency ratio (C.R.). The main objective to calculate consistency ratio is to ensure the preference rating. All the opinions are considered as consistent and accurate when the consistency index is greater than 0.10 . In present study, the value of consistency ratio is 0.084 and consistency index is 0.11 . 
Table 5 Normalizing table

\begin{tabular}{|l|c|c|c|c|c|c|c|c|}
\hline \multicolumn{1}{|c|}{ Factors } & Mixing & Building & Extruding & Calendaring & Curing & Finishing & Milling & Avg. \\
\hline Mixing & 0.13 & 0.08 & 0.29 & 0.23 & 0.12 & 0.24 & 0.25 & 1.35 \\
\hline Building & 0.35 & 0.22 & 0.26 & 0.13 & 0.19 & 0.18 & 0.18 & 1.51 \\
\hline Extruding & 0.04 & 0.08 & 0.09 & 0.22 & 0.10 & 0.17 & 0.21 & 0.92 \\
\hline Calendaring & 0.03 & 0.08 & 0.02 & 0.05 & 0.07 & 0.10 & 0.03 & 0.38 \\
\hline Curing & 0.39 & 0.40 & 0.29 & 0.23 & 0.34 & 0.19 & 0.23 & 2.07 \\
\hline Finishing & 0.02 & 0.04 & 0.02 & 0.02 & 0.07 & 0.04 & 0.03 & 0.24 \\
\hline Milling & 0.04 & 0.08 & 0.03 & 0.13 & 0.10 & 0.08 & 0.07 & 0.53 \\
\hline
\end{tabular}

Consistency Ratio $=\frac{\text { Consistency Index }}{\text { Random Index }}$

Value of Consistency Index $=\frac{\lambda \max -n}{n-1}$

$\lambda \max =\frac{\Sigma \mathrm{Ci}}{\mathrm{n}}$

Table 6 Value of Random index

\begin{tabular}{|l|l|l|l|l|l|l|l|l|l|l|}
\hline $\mathrm{n}$ & 1 & 2 & 3 & 4 & 5 & 6 & 7 & 8 & 9 & 10 \\
\hline $\mathrm{RI}$ & 0 & 0 & 0.58 & 0.9 & 1.12 & 1.24 & 1.32 & 1.41 & 1.46 & 1.49 \\
\hline
\end{tabular}

\subsection{STEPS 3\&4: Calculation of Relative Weights \& Ranking of Alternatives}

AHP method uses geometric mean method to reach on a single result in decision making when there are more than one expert. The various manufacturing processes are ranked by using final judgment sheet which is formed by taking geometric mean of individual opinions.

\section{RESULT AND DISCUSSION}

Manufacturing processes plays an important role in the economics of any tyre manufacturing company. The process of finding out a critical process always requires a lot of experience and literature survey. The selected manufacturing processes were ranked by AHP. The results shows that curing is the most critical process in tyre manufacturing followed by building and mixing as shown in table 5 (Based on their average value). The consistency of these results are also verified by calculating the value of consistency ratio, which is below 0.1 . Hence, the judgement is consistent.

Table 7 Ranking Table

\begin{tabular}{|c|l|c|c|}
\hline S.no. & \multicolumn{1}{|c|}{ Processes } & Weights & Rank \\
\hline 1 & Curing & 0.30 & 1 \\
\hline 2 & Building & 0.22 & 2 \\
\hline 3 & Mixing & 0.19 & 3 \\
\hline 4 & Extruding & 0.13 & 4 \\
\hline 5 & Milling & 0.08 & 5 \\
\hline 6 & Calendaring & 0.05 & 6 \\
\hline 7 & Finishing & 0.03 & 7 \\
\hline
\end{tabular}




\section{CONCLUSION}

According to the result obtained by AHP analysis and reviews of various experts curing of tyre is the most critical process followed building in tyre manufacturing industries. To enhance the quality of tyre and to sustain in global competition industry need to optimize these process. In future author will extend the work by optimizing the process parameters of this critical manufacturing process.

\section{REFERENCES}

[1] Dr. Naveen Kumar, Indian Tyre Industry Turning the wheels of Progress, Thought Arbitrage Research Institute (TARI) for Automotive Tyres Manufacturers' Association(ATMA), (2018), 1-80

[2] Saaty, T.L, The Analytic Hierarchy Process, McGraw-Hill, New York, NY. (1980).

[3] Rathore, P., Kota S., \& Chakrabarti, A, Sustainability through remanufacturing in India: a case study on mobile handsets, J Clean Product, 19 (15), 2011, 1709-1722

[4] Jayamani, E., Perera, D S., Soon, K H., \& Bakri, M K B., Application of Analytic Hierarchy Process (AHP) in the analysis of the fuel efficiency in the automobile industry with the utilization of Natural Fiber Polymer Composites (NFPC), Materials Science and Engineering, 1, 2017, 1-6.

[5] Lebreton, B., \& Tuma, A, A quantitative approach to assessing the profitability of car and truck tire remanufacturing, Int J Prod Econ, 104(2), 2006, 639-652

[6] Sasikumar P., Kannan G., \& Haq, AN, A multi-echelon reverse logistics network design for product recovery - a case of truck tire remanufacturing, Int J Adv Manuf Technol,49(9), $2010,1223-1234$

[7] De Souza, CDR, \& Ma'rcio de Almeida, DA, Value chain analysis applied to the scrap tire reverse logistics chain: an applied study of co-processing in the cement industry, Resour Conserv Recycl, 78, 2013, 15-25

[8] Kannan, D., Diabat, A., \& Shankar, KM, Analyzing the drivers of end-of-life tire management using interpretive structural modeling (ISM), Int J Adv Manuf Technol, 72(912), 2014, 1603-1614

[9] Gupta, V., Acharya, P., \& Patwardhan, M, Monitoring quality goals through lean Six-Sigma insures competitiveness, Int J Product Perform Manag, 61(2), 2012, 194-203

[10] Gupta, V., Acharya, P., \& Patwardhan, M, A strategic and operational approach to assess the lean performance in radial tyre manufacturing in India: a case based study, Int J Product Perform Mana, 62(6), 2013, 634-651

[11] Visakh MJ., \& Aravind S, Optimization using simulation design of experiments and value stream mapping, Int J Des Manuf Technol, 5(3), 2014, 194-203

[12] Wojtaszak, M, Problem solving techniques as a part of implementation of six sigma methodology in tire production. Case study, Manag Syst Prod Eng Res Dev, 3(19), 2015, $133-137$

[13] Chatterjee, P., Athawale, V. M, \& Chakraborty, S., Material Selection Using Complex Proportional Assessment and Evaluation of Mixed Data Methods, Material and Design, 32(2), 2011, 851-860.

[14] Voogd, H , Multicriteria Evaluation with Mixed Qualitative and Quantitative Data, Environment and Planning Bulletin, 9(2), 1982, 221-236.

[15] Voogd, H. multicriteria evaluation for urban and regional planning, (Pion, London 1983) 
[16] Hajkowicz S. \& Higgins A, A Comparison of Multiple Criteria Analysis Techniques for Water Resource Management, European Journal of Operation Research, 184(1), 2008, 255 265.

[17] Ustinovichius, E., Zavadskas, K., \& Podvezko, V, Application of a Quantitative Multiple Criteria Decision Making (MCDM-1) Approach to the Analysis of Investments in Construction, Control and Cybernetics, 36(1), 2007, 251-268.

[18] Jeffreys I, The Use of Compensatory and Non-Compensatory Multi-Criteria Analysis for Small-Scale Forestry, Small-Scale Forest Ecol Manage Policy, 3(1), 2004, 99-117.

[19] Chen M. S, A New Method for Tool Steel Materials under Fuzzy Environment, Fuzzy Sets and System, 92 (3), 1997, 265-274.

[20] Rao, R. V., \& Davim, J. P, A Decision-Making Framework Model for Material Selection Using a Combined Multiple Attribute Decision-Making Method, The International Journal of Advanced Manufacturing Technology, 35(7-8), 2008, 751-760.

[21] Revisions http://atmaindia.org/indian-tyre-industry/ About number of companies $40 \%$ used in 2 wheelers

[22] https://economictimes.indiatimes.com/tyres/indian-tyre-exports-to-cross-rs-12000-crorethis-fiscal/articleshow/66952881.cms

[23] https:/economictimes.indiatimes.com/news/economy/agriculture/high-consumption-ofrubber-may-trigger-its-production-growth-in-india/articleshow/66432657.cms

[24] https://www.iaeme.com/Authorinfo.asp International Journal of Advanced Research in Engineering and Technology (IJARET) U

[25] fhttp://tari.co.in/wp-content/uploads/2018/03/India-tyre-industry-research-Report2018.cdr_.pdf

[26] Bhattacharya. S, and Raju V, A Condorcet Voting Theory based AHP method for Contractor Selection in Civil Engineering Industry. International Journal of Civil Engineering and Technology, 8(6), 2017, pp. 595-604.

[27] Dr.Manoranjan Dash, Dr. Kamalakanta Muduli, Mr.Sasanka Sekhar Mishra, Prof. John Pumwa and Dr. Sunil Kar, A Swot-Ahp Based Approach to Investigate Waste Management Issues in Health Care Supply Chain in Odisha, International Journal of Mechanical Engineering and Technology, 9(10), 2018, pp. (1074)-(1084).

[28] Sherif Mostafa and Jantanee Dumrak, An AHP Model for Matching Leagile Strategies for the off-Site Manufacture in Australia, International Journal of Industrial Engineering Research and Development (IJIERD), Volume 4, Issue 3, September - December (2013), pp. 30-49

[29] Parul Gupta and R.K. Srivastava, Analysis of Customer Satisfaction in Hotel Service Quality using Analytic Hierarchy Process (AHP), International Journal of Industrial Engineering Research and Development (IJIERD), Volume 2 Issue 1, May - October (2011), pp. 59-68

[30] Atul K. Shrivastava, Dr. S.K. Kumara Swamy, Anil Midathada and Uday K. Ravella Analysis of The Barriers for Implementing Green Supply Chain Management (GSCM) Practices on Organic Irrigation: An Analytical Hierarchy Process (AHP) Approach. International Journal of Mechanical Engineering and Technology, 8(7), 2017, pp. 14651473. 